\title{
Greener Campus Awareness among International Students for a better Sustainable Campus Culture
}

\author{
Shankar Chelliah, Bilal M.A Atteyat, Lee Ming Huoy \\ Universiti Sains Malaysia
}

\begin{abstract}
The objective of this study the green awareness among international within Universiti Sains Malaysia (USM) campus. Green awareness within each individual are important. Especially for university students, after graduate from university each student will entering to different companies or cooperates. The awareness of green practice of students help to influences on companies and cooperates to increase green practices and reduce carbon-footprint, especially when time past students might end-up take the role as manager or director, which able lead and bring in decision regarding to green practices. This is important not only for companies to create competitive advantages and company's reputation, but is a contribution for the planet. Without proactive green practices; pollution and wastes will be pushing our planet towards danger. Companies and cooperates able to bring development and profit to the country but result harm and massive pollution to the planet. Taking a chance in company practice towards green practice is the only chance to reduce the pollution to planet. Green awareness within students and public are relatively important, everyone person having the awareness able to help world, protecting and sustaining world resource is no a responsible for particular person, but is the responsible for each individual that living in the one and only planet earth.
\end{abstract}

Keywords: Green Awareness. Sustainable, Environment Awareness, Behaviour

\section{INTRODUCTION}

Sustainable environment is considered as one of the most important knowledge to be educate in higher education. Awareness within university's students able to bring in positive influence toward nations, companies, industries and government. Environment awareness can be applied in educating, designing, industries innovation, recycling, waste managing, organic foods offering and sustainable development. Most researchers have conducted an extensive research on environmental sustainability attempts, but only few addressed the campus culture or behaviour aspect toward environment sustainability (Levy \& Marans, 2012).

Thus,(Sanusi. Z \& Khelghat-Doost, 2008) at Universiti Sains Malaysia (USM) had implemented educational sustainable development (ESD) that benefited the campus, and influence the society especially through Regional Centre of Expertise (RCE). RCE which lead by USM's coordinated role of educational sustainable development (ESD), that emphasize sustainable development, and implement green related educational content and practice. In Malaysia, green awareness within public and students are slowly being recognize, but as compare with certain develop country, Malaysia still not yet comprehensive enough in term of waste manage, pollution policy and knowledge. Therefore, the awareness among international students come across to be the highlight of the research, which allowing USM to understand the awareness level for different nationality students and bring in correct method to educate each student.

\section{Problem Statement}

The research among international students at Universiti Sains Malaysia (USM) still remain unknown. Required further investigation upon attitude towards greener campus awareness, and campus culture sustainability, as well as build up methods that can use by USM to fester up the environment behaviour sustainability (Levy \&Marans, 2012). Three factors believed able to influence individual towards pro-environment behaviours, which are; social incentives; material incentives; and prompts/reminders. Three factors able to support the development of pro-environment behaviours: education, engagement, and assessment (Levy \& Marans, 2012).

Conducting a comprehensive assessment about USM greener campus awareness, and its effect on campus culture sustainability, through testing international students attitude and awareness of pro- 
environment behaviours, environmental knowledge, environmental concern, environmental awareness, social incentive, material incentive, and prompts/remainders. These all facilitate USM Committees in addressing any issues may raise either within or outer (societies) of the campus, and find a solution to overcome these issues, by figuring out the weakness to improve, strength to sustain, and harmful to eliminate which could results in a better campus culture toward environment, which positively influence on other Malaysian Universities to take advantage from this research.

\section{RESEARCH OBJECTIVE}

The objective of this research is to investigate factors that contribute in the green awareness of international students' in USM. To obtain the result, variables with the effects will be measure. The research objectives of this study will be as follows:

1. To examine USM international students' awareness toward campus culture of environmental sustainability.

2. To examine USM international students' awareness of green campus environment toward overall campus culture sustainability.

3. To examine the influences of USM campus culture of environment sustainability toward student's way of perceive, behave, and lifestyle.

\section{RESEARCH QUESTIONS}

This study illustrates a method for USM committees to undertake for building a greener campus environment that will create eventually sustainable campus culture for Universiti Sains Malaysia(US M). These three methods were applied by Levy and Marans (2012) to address the pro-environmental behaviour education, engagement, and assessment. Based on that I have recommended the below three hypotheses.

1. Does cross-cultural differences effect USM's international students to be aware of greener campus environment?

2. Do aspects of current campus culture of environment sustainability on USM students effect their lifestyle, choice, and perceive environmentally?

3. Does USM improve greener campus awareness among international students, able to bring better campus cultural sustainable?

\section{Significance OF STUdy}

This study focused on constructing a strong base of "culture of environmental sustainability" through enhancing greener campus awareness at Universiti Sains Malaysia (USM). These could be conducted through three factors that are implemented by University of Michigan (UM) 2012 social incentive, material incentive and prompts/remainders, environmental knowledge and environmental concern (Chan \&Lau, 2000), and pro-environmental behaviour (BCG report, 2009). encouraging USM's international students behaving in more environmental greener way for a better overall sustainable campus culture.

\section{LITERATURE REVIEW}

With increasing a company consideration of green environment through daily decisions exert a high pressure in figuring out greener ways that effect positively on the environment (Chien \&Shih, 2007).In year 2015, Petaling Jaya, Malaysia has announced a warning for outdoor holiday specially in hot and dry season, where many diseases such as leptospirosis from unclean river, waterfall, and rubbish left behind. The dry season is where the risk is highest, Health Ministry director-general Datuk Dr Noor Hisham Abdullah stated that leisure areas near streams and waterfall can be polluted from the rubbish and food remain on the area side which bring more diseased animals (Sukumaran, 2015).

\subsection{Pro-Environment Behaviour}

Pro-Environment Behaviour defined by Kollmuss and Agyeman (2002) as "behaviour that consciously seeks to minimize the negative impact of one's actions on the natural and built world", (e.g reduce resource and energy consumption, reuse recycle resources, minimize waste production). Pro-environment behaviour defined by another research as a behaviour that tend toward minimizing the harm to the environment as much as possible, and even maintain protecting it (Steg\& Vlek, 2009). 
Behaving environmentally is not to put our priority for personal gain and gratification, but for future to gain a better environment and benefits for whole societies (Mc Carty \&Shrum, 2001; Kim \& Choi, 2005). External and internal factors have some influence either positive or negative, on proenvironment behaviour external factors (Kollmuss \& Agyeman, 2002).

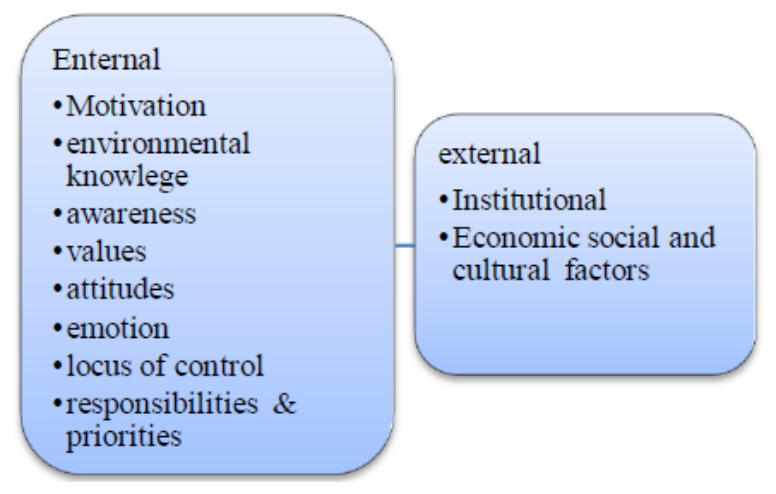

Figure1. Factores effect Pro-enviroment behaviour. Kollmuss \& Agyeman, (2002)

\subsection{Environmental Knowledge}

Individuals have a relieve knowledge about the environment, is the one who took environmentally action (Bord et al., 2000). Environmental knowledge as "sets of ecological knowledge that an individual has environmental topics" (Conraud-Koellner \& Rivas-Tovar, 2009). Both of the author believe that the major influence on environmental knowledge results from ecological ethnocentrism, degree of information, past behaviour and perceptions about green products. In addition, environmental knowledge founded by another researcher as the amount of knowledge that individual obtain regarding to environment matters (Chan \& Lau, 2000).

Egyptian universities have focused on investigating the influence of three cognitive and attitudinal factors on gender differences in green purchasing behaviour (Mostafa, 2007). Environmental knowledge defined as a "knowledge that people know about the environmental, key relationships leading to environmental impacts, an appreciation of the 'whole systems', and collective responsebilities necessary for sustainable development". Environmental education has focused mainly on the learner's knowledge, attitudes and behaviour in relation to environmental phenomena and environmental problem (Lundholm, 2005).A number of study investigating students' scientific knowledge about understanding of environmental problems (Gomez-Granell \& Cervera-March, 1993; Gambro and Switzky, 1996; Ivy et al, 1998).

\subsection{Environmental Concern}

Studying the concern of the students toward the current environment issues is an important method to investigate their environmental attitude and behaviour. Environmental concern has defined environment concern related to egoistic, social altruistic, and biospheric value orientations (Stem and Dietz, 1994). Environment concern is a predictive of environmental behaviour including recycling (Schultz \& Oskamp, 1996). Perceiving environmental dangers were a result of three contribution factors-economic sacrifice, personal activities, and political activities (Clark \& Stewart, 1997). Environment concern has no immediate effects on willingness to be environmentally friendly, but was allied to psychological consequences of environmental friendless and propose the findings may involve a meditational role for psychological consequences (Abdul-Muhmin, 2007). Environment concern as the arousing and awareness for consumers to the natural resources are limited and environmental under threat (Kalaftis\& et al., 1999). Boosting the people concern about the environment will end up positively effect on their purchasing activities (Kalafatis \& et al., 1999)

\subsection{Environmental Awareness}

Environmental awareness were classified into two characteristics (Xi\& et al, 1998); Perception of environmental problems and behavioural inclination to protect the environment. The behaviour inclination separated into two figures to protect the environment; first, the environmental value as people perceive balance between environmental protection and economic development, and also the willingness to pay to save the environment. Second, attitudes toward participation in protecting the environment. 
The solution of environmental problems must beginwith modification of human attitudes (Zhenmin \& Xiaohua, 2002; Abdul-Wahab, 2008). The attitude toward environmental concernvary by gender, age, education level and other social variables (Brody, 1997). The environmental awareness was influenced by differs in age range, with older groups the more consistent response and higher overall index of environment awareness (Ziadat, 2010).

\subsection{Green Supply Chain Management}

However, with regard for increasing the global awareness toward environment protection, green supply chain management being implemented by the corporations to enhance their core competitive advantage (Ghobakhloo \&et all, 2013).Green Supply Chain Management (GSCM) is considered one of the innovative idea that is fast gain attention of industry, and attract the interest of many researcher and practitioners of operations and supply Chain Management (Rao, 2007).

Based on the main objective of green manufacturing process, which is reducing the use of virgin material and other resources like energies to ultimately reduces the amount of waste at manufacturing stage (Ghobakhloo \& et all, 2013). Currently waste management monitoring among the companies productions process increased. There are three main ways to minimize energy and resource consumption defined by (Linnhoff, 1993; Boustead \& Hancock, 1979; Lee \&et all, 1995) respectively, Pinch analysis, Industrial energy, and resource consumption. Green distribution is an extra important adding on green SCM. Defining green distribution as; "transportation service that has a lesser or reduced negative impact on human health and the natural environment when compared with competing transportation services that serve the same purpose" (Bjorklun, 2010).

Further, implementing of GSCM way has a positive effect on environmental and financial perform ance (Chien \& Shih, 2007): that increased environmental performance results in boost corporation profit and market share. As well as they stated in their research, an execution of green supply chain management can guarantee both corporation itself and its suppliers obey environment regulation. Suppliers can influence in reducing transaction costs and promote recycling and reuse of raw materials, also corporations can reduce the production waste and hazardous, which preventing the corporation from being fined as a result of violation environmental regulations.

\subsection{Campus Culture Sustainability}

Sustainable development is one of the important topic for last decade and will maintain onward to be a critical for the future research (Patrick \&et al., 2002), also an important part of many corporate social agendas (Linda Too \& Bhishna Bajracharya, 2013). Both of the author stated discovering and evidence presented in the United Nations Climate Change Conferences in Mexico (2010) and South Africa (2011) have the need for paradigm shift toward constructing a low-carbon sustainable society to control over the climate change (Velazqmuez Contreras, 2002).

[...] a higher education institution that addresses, involves and promotes the minimisation of environmental, economics, societal and health negative effects in the use of their resources [in] its main functions of teaching, research, outreach and partnership, and stewardship to [help] society make the transition to sustainable lifestyles.

the impact and significance of the cultural facets of conversions to sustainable future for business institutions and engineering design are not regularly covered in university curriculum (Patrick \&et al., 2002). The author also hope to motivate the course developer (universities) to take action in considering the cultural topics and approaches as extra tools to meet the education challenges for a sustainable future. Further also the authors believe that through understanding the nation culture influence is important when evaluation and integrating sustainability and environmental issues, and these all need to be understand by the firms to be globally successful (Patrick\& et al., 2002).

\subsection{Theoretical Model}

Stern et al. s (1999) constricted value-belief model (VBN). This model hold personal norms (internal, sense of obligations to act accordingly, determined by values). In VBN model three individual's values are altruistic (obligations that individual sense to others), egocentric (individual's desire to protect own self), or biocentric (individual's responsibility in protracting environment and ecosystem), (Azizan \&Wahid 2012).In TRA model has subjective norms and social pressures is a function of the perceived expectation by other individuals or group who are important or close to a person (e.g. friends, peers, and neighbours) as well as the person's motivation to comply with these expectation (Fishbein, and Ajzen, 1975). 


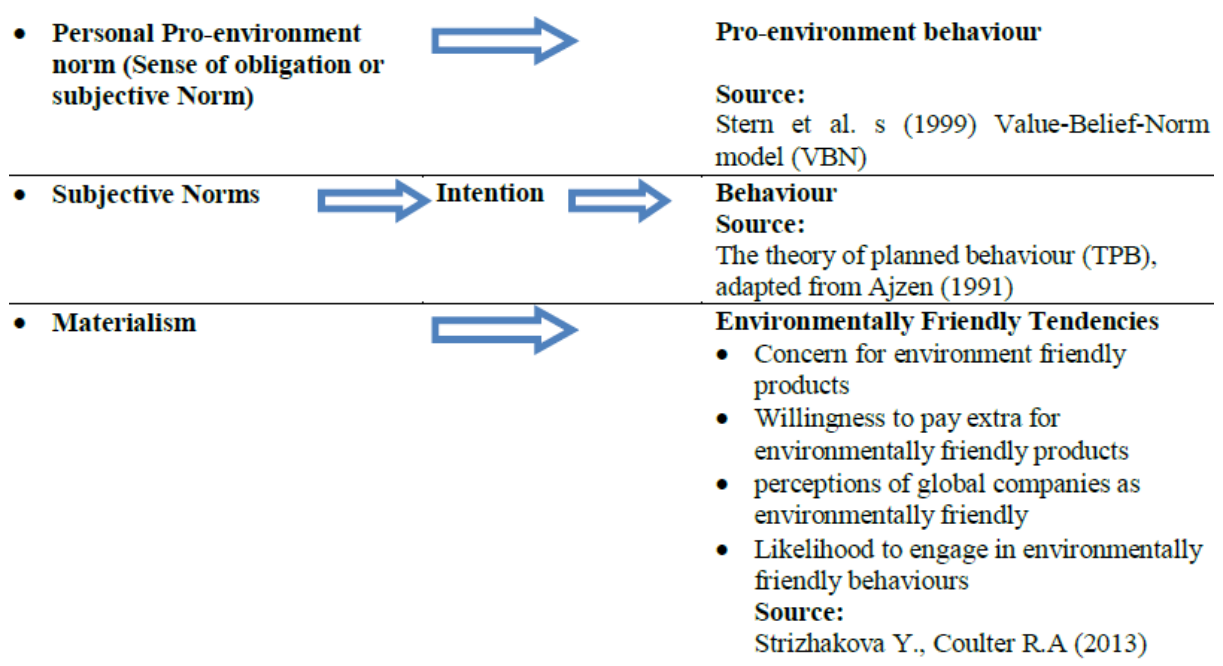

Figure2. Theories of $V B N, T P B$, and Materialism

\section{Methodology}

Methodology chapter illustrate theoretical analysis of the methods that being conducted in this research. This chapter will include research model and development of hypothesis, research design, population; sample size and sampling technique, scale and measurement, and statistical data analysis. As for data collection, will conduct within primary and secondary resource.

\subsection{Conceptual Framework}

Theoretical framework of this research was constricted based on the literature review. Constricting a measurement model from literature review and modify the model that can predict the result of greener campus awareness as dependent variable and influencing variables (independent variables). This research model, shown in Figure 3 will illustrate the relationship between independent variables and dependent variables.

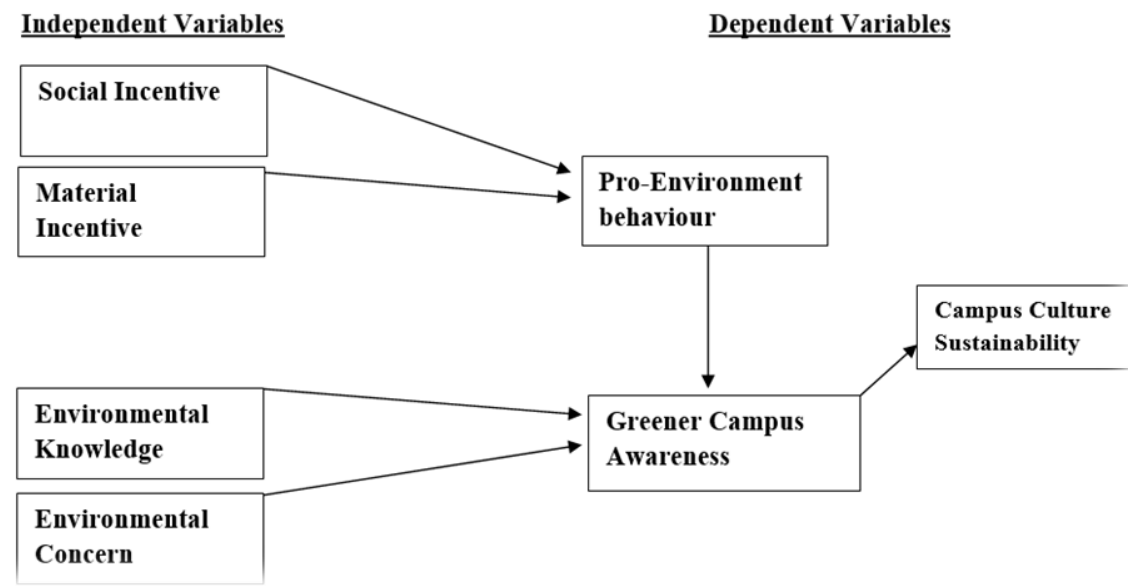

Figure3. Research Framework of Greener Campus Awareness

\subsection{Research Hypothesis}

Hypothesis developed as below table;

\begin{tabular}{|l|l|}
\hline $\mathbf{H}_{\mathbf{1}}$ & There is a significant relationship between Social Incentive and Pro-environment Behaviour. \\
\hline $\mathbf{H}_{2}$ & There is a significant relationship between Material Incentive and Pro-environment Behaviour. \\
\hline $\mathbf{H}_{3}$ & There is a significant relationship between Environmental knowledge and Greener Campus Awareness. \\
\hline $\mathbf{H}_{\mathbf{4}}$ & There is a significant relationship between Environmental Concern and Greener Campus Awareness. \\
\hline $\mathbf{H}_{5}$ & $\begin{array}{l}\text { There is a significant relationship between Pro-environmental Behaviour and Greener Campus } \\
\text { Awareness. }\end{array}$ \\
\hline $\mathbf{H}_{\mathbf{6}}$ & $\begin{array}{l}\text { There is a significant relationship between Greener campus awareness and Campus culture } \\
\text { sustainability. }\end{array}$ \\
\hline
\end{tabular}




\subsection{Sample Size and Sampling Technique}

The questionnaire was distributed for 80 respondents, who are randomly selected from international students in USM.The questionnaire was distributed among international students at Universiti Sains Malaysia (USM) in main campus and engineering campus regardless of education level (e.g. undergraduate, master and $\mathrm{PhD}$ ). The sampling method using unrestricted non-probability method and respondents selected were using the convenience approach in a natural environment.

\subsection{Scale and Measurement}

For sections 1 through 6 an interval scale used were respondents had to choose whether they agree or disagree. The interval scale was set from 1-5; strongly disagree -1 , disagree -2 , neutral -3 , agree -4 and strongly agree -5 .

Table1. Measurement of Independent Variables and Dependent Variable

\begin{tabular}{|c|c|c|c|}
\hline Section No. & Variable name & No. of Items & Source \\
\hline 1 & Pro-Environmental behaviour & 8 & BCG report 2009 \\
\hline 2 & Environmental knowledge & 5 & Chan and Lau, 2000 \\
\hline 3 & Environmental Concern & 5 & Chan and Lau, 2000 \\
\hline 4 & Social incentive & 6 & Strizhakova Y., Coulter R.A (2013) \\
\hline 5 & Material incentive & 3 & Strizhakova Y., Coulter R.A (2013) \\
\hline 6 & Environment awareness & 3 & Wesselink R., et all (2014) \\
\hline 7 & Campus cultural sustainability & & Levy and Marans (2012) \\
\hline
\end{tabular}

\section{ANALYSIS AND ReSUlt}

A total of 80 respondents were answered the questionnaires regarding to this study. The majority of the respondents were male, $61(76.3 \%)$ male respondents, and $19(23.8 \%)$ of the 80 respondents were female. Based on the aging group being tested on this survey which divided into 4 groups. First group aged under 20 years old were $11(13.8 \%)$ of the 80 respondents. The majority were aged 21-25 years old, which shown in table 4.1 there were 28 (35\%) out of 80 respondents. Also there were 23(28.8\%) respondents categorize under 26-30 years old and 18 (22.5\%) respondents are above 30 years old.

There is a variety of nationality were being selected randomly. The majority were Arabian which are $36(45 \%)$ of the respondents as stated in table 4.1. Followed by Indonesian $12(15 \%)$ of the respondents, 4 (5\%) were Iranian, 6 (7.5\%) were Thai, 2 (2.5\%) were Japan, German and Australian 1 $(1.3 \%)$ of respondents, and $18(22.5 \%)$ from other countries.

Based on the study program being involved, as shown below most of the respondents were undergraduates students 34 (42.5\%) of the respondents, followed by $\mathrm{PhD}$ students were 29 (36.3\%), and master students were $17(21.3 \%)$. However, the majority of the respondents were Science students $51(63.8 \%)$ of the respondents, $15(18.8 \%)$ were Art students, and14 (17.5\%) were others major of study.

Moreover, there are two status of candidacy part time and full time, the majority are full time which are $63(78.8 \%)$ of the respondents, $4(5 \%)$ of the respondents are part time, and $13(16.3 \%)$ of the respondents are exchange students. The majority of them are living inside the campus which are 45 $(56.3 \%)$ of respondents, and $35(43.8 \%)$ of respondents are living outside campus.

\section{GoOdness OF MEASURE}

\subsection{Reliability of Measure}

The reliability test chosen was the Cronbach Alpha Test. The test was conducted on different instrument of the variables: pro-environmental behaviour (PEB), Environmental Knowledge (EK), Environmental Concern (EC), Social Incentive (SI), Material Incentive (MI), Campus Culture Environment (CCE), and Greener Campus Awareness (GCA). It is a reliability measure coefficient that reflects the goodness of the items through positively correlated to one another. The result stated in table 4.2 and Appendix B.

Table2. Summary of Reliability Analysis

\begin{tabular}{|l|c|c|c|}
\hline Variable & $\begin{array}{c}\text { Cronbach's } \\
\text { Alpha }\end{array}$ & $\begin{array}{c}\text { Number of item } \\
\text { deleted }\end{array}$ & Total Item used \\
\hline Pro-Environmental Behaviour (PEB) & 0.762 & - & 8 \\
\hline Environmental Knowledge (EK) & 0.687 & - & 5 \\
\hline Environmental Concern (EC) & 0.724 & - & 5 \\
\hline
\end{tabular}


Greener Campus Awareness among International Students for a better Sustainable Campus Culture

\begin{tabular}{|l|c|c|c|}
\hline \hline Social Incentive (SI) & 0.669 & - & 6 \\
\hline Material Incentive (MI) & 0.824 & - & 3 \\
\hline Campus culture sustainability (CCS) & 0.530 & - & 7 \\
\hline Greener Campus Awareness (GCA) & 0.815 & - & 5 \\
\hline
\end{tabular}

Based on table 2 summarize the results of Cronbach's Alpha value for the measuring items of independents and dependents variables. Cronbach's Alpha for attributive satisfaction was low at 0.670 , and the accepted minimum value is 0.50 (Sekaran, 2003). While Kline 1999, proposed that the Alpha values ranged from 0.89 is reliable value. From table 4.2, all the Cronbach's Alpha values are higher than 0.65 except CCS where the Alpha value is low at 0.530 .

\subsection{Descriptive Analysis}

The descriptive analysis of the variables illustrated in table 3.

Table3. Overall Descriptive Statistics of the Study Variables

\begin{tabular}{|l|c|c|}
\hline Variable & Mean & Standard Deviation \\
\hline Pro-Environmental Behaviour (PEB) & 3.608 & 0.7073 \\
\hline Environmental Knowledge (EK) & 3.62 & 0.692 \\
\hline Environmental Concern (EC) & 3.85 & 0.702 \\
\hline Social Incentive (SI) & 3.59 & 0.636 \\
\hline Material Incentive (MI) & 3.35 & 0.869 \\
\hline Campus culture sustainability (CCS) & 3.60 & 0.577 \\
\hline Greener Campus Awareness (GCA) & 4.245 & 0.6818 \\
\hline
\end{tabular}

\subsection{Hypothesis Testing}

\subsubsection{Correlation Analysis}

All the correlation are positive, except campus culture sustainable to environmental knowledge (CCS to EK) where the significant between them are too low. Whereas the rest indicate that there is a significant relationship between independent and dependent variables.

Table4. Pearson's Correlation Coefficients of the Study Variables

\begin{tabular}{|l|l|l|l|l|l|l|l|}
\hline & PEB & EK & EC & SI & MI & EA & CCS \\
\hline PEB & 1 & & & & & & \\
\hline EK & $0.404^{* *}$ & 1 & & & & & \\
\hline EC & $0.483^{* *}$ & $0.297 * *$ & 1 & & & & \\
\hline SI & $0.360^{* *}$ & $0.304 * *$ & $0.332^{* *}$ & 1 & & & \\
\hline MI & $0.562^{* *}$ & $0.300^{* *}$ & $0.376^{* *}$ & $0.508^{* *}$ & 1 & & \\
\hline GCA & $0.330^{* *}$ & $0.456^{* *}$ & $0.479^{* *}$ & $0.439^{* *}$ & $0.253^{*}$ & 1 & \\
\hline CCS & $0.371^{* *}$ & 0.135 & $0.355^{* *}$ & $0.321^{* *}$ & $0.376^{* *}$ & $0.217 * *$ & 1 \\
\hline
\end{tabular}

**Correlation is significant at the 0.01 level (2-tailed).

*Correlation is significant at the 0.05 level (2-tailed).

As a result, from the correlation coefficients data, below are the hypotheses that accepted and reject, which summarise as table below.

Table5. Summary for Hypothesis Testing

\begin{tabular}{|c|c|c|c|}
\hline Hypotheses & Description & Results & $ß$ Value \\
\hline H1 & $\begin{array}{l}\text { Social Incentive is positively related to Pro-Environmental } \\
\text { Behaviour }\end{array}$ & $\begin{array}{l}\text { Rejected } \\
\text { Not significant }\end{array}$ & $\beta=0.111$ \\
\hline H2 & $\begin{array}{l}\text { Material Incentive is positively related to Pro-Environmental } \\
\text { Behaviour }\end{array}$ & Accepted & $\beta=0417$ \\
\hline H3 & $\begin{array}{l}\text { Pro-Environmental Behaviour is positively related to } \\
\text { Greener Campus Awareness }\end{array}$ & $\begin{array}{l}\text { Rejected } \\
\text { Not Significant }\end{array}$ & $\beta=0.012$ \\
\hline H4 & $\begin{array}{l}\text { Environmental Knowledge is positively related to Greener } \\
\text { Campus Awareness }\end{array}$ & Accepted & $\beta=0.336$ \\
\hline H5 & $\begin{array}{l}\text { Environmental Concern is positively related to Greener } \\
\text { Campus Awareness }\end{array}$ & Accepted & $\beta=0.360$ \\
\hline H6 & $\begin{array}{l}\text { Greener Campus Awareness is positively related to Campus } \\
\text { Culture Sustainability }\end{array}$ & $\begin{array}{l}\text { Rejected } \\
\text { Not Significant }\end{array}$ & $\beta=0.184$ \\
\hline
\end{tabular}




\section{DiscuSSION AND CONCLUSION}

Result shows pro-environmental behaviour had a significant relationship with its Material incentive where the respondents are aware of selecting the materials that are environmentally friendly and easy to recycle that materials. Whereas social incentive had no relationship with pro-environment behaviour that based on the pervious analysis. In hypothesis $\mathrm{H}^{4}$ and $\mathrm{H}^{5}$ Environmental Knowledge and Environmental Concern were positively related to greener campus awareness. That indicated the respondents are knowledgeable and in the same time concern about the current situation of greener environment. Kalafatie, et al 1999, boosting the people concern about the environment will end up positively effect on their purchasing activities.

In hypothesis test $\mathrm{H}^{3}$ pro-environment behaviour had no relationship with greener campus awareness as being illustrated in the results. Most of the researchers had found that pro-environment and environmental awareness are both of these variables are week and almost there is no relationship to each other. Lastly, from the result of $\mathrm{H}^{6}$ predicts that there is no significant between greener campus awareness and campus culture sustainability. Which indicate there is no relationship between both of the variables, and greener campus awareness will not affect campus culture sustainability in either way.

\section{LIMITATION}

The research was conducted on a small sample size due to the time limit. Results with larger number of participants would have showed better interpretation. By considering this very limitation, it is recommended that future research shall utilize broader demographic profile to analyse respondents. Secondly, the research was only conducted for international students in main and engineering campus of Universiti Sains Malaysia, hence the research cannot be applied to all the students in Malaysia. Thirdly, not many variables were tested there is a chance of availability of intermediating variables. Fourth, respondent's honesty will influence the findings in this study. It because some of the respondents answer the questionnaire without a deep reading. This makes the result I get not accurate to reflect the real situation. Finally, the number of international females in Universiti Sains Malaysia are limited which hindered the chance of making a better assumption about the study.

\section{Future RESEARCH}

1) This research need to be conducted on wider demographic area and includes all the students local and international in all Universities in Malaysia, because the more are the participants the more accurate measure of this study.

2) There is a chance of including intermediate variables or dependent or independent variables on the current model to make the study more reliable and accurate.

3) Encouraging universities students to conduct research on the green environment as part of their assignment for enhancing their knowledge and awareness toward current situation of the environment and take initiative to protect it.

4) Future research should focus on specific topic such as recycling, waste management, and environmentally friendly paper.

\section{SUGGESTION FOR ENVIRONMENTAL IMPROVEMENT}

Students suggestion for campus environment improvement and increase the awareness between USM students to take initiative in taking care of the environment. Suggestion provided as below;

- Using of Animated signboard in the campus to enhance the students to go green.

- Organizing workshop and seminar on how serious the impact of global warming, pollution and etc to raise students awareness.

- Opening shops for healthy and organic food.

- Organize activities and public speaking about environment.

- Organize environment campaign (go green campaign).

- Encourage students to use USM bus rather than their own cares.

- Rewards the students through certificates.

- Encourage students to use reusable staff, such as bottle (BPA Free) to reduce plastic trash. 
- Applying Solar cell panel in campus.

- Enhancement during classroom teaching and get the students to observe and apply directly.

- Educating students through social media and TV.

- More recycle bins.

\section{Conclusion}

In conclusion the study had reached its objectives in investigating the influence of social incentive, material incentive, environmental knowledge, environmental concern and pro-environmental behaviour on greener campus awareness and which lead to a better campus culture sustainability. The results stated that material incentive, and environmental knowledge and environmental concern are significant influence greener campus awareness. As conclusion, with more concern and knowledgeable among students, the more likely for students to behave in environmentally friends and take action to protect the environment.

\section{ACKNOWLEDGEMENT}

We would like to thank the Malaysian Ministry of Higher Education in providing the fund through Fundamental Research Grant Scheme (FRGS:203/PMGT/6711399) to perform the current study as part of a bigger research area.

\section{REFERENCES}

Levy, .B.,Marans .R.(2012),"Towards a campus culture of environmental sustainability recommendations for a large university". International Journal of Sustainability in Higher Education, vol. 13 Iss 4 pp. 365-377.

Sanusi, .Z., Khelghat-Doost .H.(2008),"Regional centre of expertise as transformational platform for sustainability". International Journal of Sustainability in Higher Education, Vol. 9 Iss 4 pp. $487-$ 497.

Eagan, .P., Cook, .T., Joeres, .E.(2002),"Teaching the importance of culture and interdisciplinary education for sustainable development. International Journal of Sustainability in Higher education, Vol.3 Iss 1 pp. 48-66.

Gladwin, T.N., Newberry, W.E. and Reiskin, E.D. (1997), "Why is the northern elite mind biased against community, the environment and a sustainable future", in Bazerman et al. (Eds), Environment Ethics and Behavior: The Psychology of Environmental Valuation and Degradation, 1st ed., New Lexington Press, San Francisco, CA, pp. 234-74.

Chien, M.K., Shih L. H. (2007), "An empirical study of the implementation of green supply chain management practices in the electrical and electronic industry and their relation to organizational performances,Int. J. Environ. Sci. Tech., 4(3): 383-394,200.

Purba, R.(2002),"Greening the supply chain: A new initiative in South East Asia, Int, J. Oper. Prod. Manage., 22(6), 632-655.

A. Gunor and S. M. Gupta, Computer and Industrial Engineering, vol. 36, pp. 811-853, 1999.

Tsoulfas, G.T.; Pappis, C.P. (2006),"Environmental principles applicable to supply chains design and operation, J. Clean. Prod., 14, 1593-1603.

M. Chobakhloo, S. H. Tang, N. Zulkifli, and M. K. A. Ariffin. (2013),"An integrated framework of green supply chain management implementation". International journal of innovation, management and Technology, vol. 4, No. 1, 2013

B. Linnhoff.(1990),"Chemical engineering research and design". vol.71, pp.503-522.

I. Boustead, and G. F. Hancock.(1979)," Handbook of industrial energy analysis". Ellis Horwood, England.

J.J. Lee, P, O'Callaghan and D. Allen.(1995),"Resources, conservation and recycling". vol. 13, pp. 37 56.

S. L. Hart, and G. Ahuja.(1996),"Business strategy and the environment". vol. 5, pp. 30-37.

M. Bjorklund, Journal of purchasing and supply management, vol. 17, pp. 11-22, 2010.

Bond, K.(2015,March 16). Why does Chamonix have some of the worst air pollution in France?.The Stare News. Retrieved from,http://www.thestar.com.my/Lifestyle/Features/2015/03/16/Whydoes-Chamonix-have-some-of-the-worst-air-pollution-in-France/. 
Sukumaran, T.(2015, March 16).Warning for outdoor holiday seekers. The Stare News. Retrieved from,http://www.thestar.com.my/News/Nation/2015/03/16/Warning-for-outdoor-holiday-seekers - Doc- Malaysians-need-to-be-more-civic-conscious-Dry-season-is-whe/.

Kollmuss, A., and Agyeman, J., (2002)," Mind the gap: why do people act enviromentally and what are the barriers to pro-environmental behaviour? Environmental education research, 8(3), 239260. http://www.elkhornsloughctp.org/ uploads/files/ 1374624996 Kollmuss\%202010\% 20env\% 20ed.pdf

Said, A.M, Ahmadun F. R, Hj L. Paim, and Masud J.,(2003),"Environmental concerns, Knowledge and practices gap among Malaysian teacher. International Journal of Sustainability in Higher Education. 4 (4), 305-313.

Stem, Paul C. and Thomas Dietz (1994)."The value basis of environmental concern". Journal of Social Issues, Volume 50, 65-84.

Abdul-Muhmin, Alhassan G. (2007). "Explaining consumers' willingness to be environmentally friendly". International Journal of Consumer Studies, Volume 31, 237-47.

Clarke, Harold D. and Marianne. (1997),"Green words and public deeds: environmental hazards and citizen response in canda and the united states". In Shades of Green: Environmental attitudes in canda and around the world, ed. Alan Frizzell and Jon Pammett, Ottawa, CA: Carleton University press, $75-103$.

Loureiro, Maria, Jill McCluskey, and Ron C. Mittelhammer (2002)."Will consumers pay a premium for eco-labelled apples?". Journal of Consumer Affairs, Volume 36, 203-19

Schultz, P. Wesley and Lynnette Zelezny (1996). "Values as predictors of environmental attitudes: evidence for consistency across 14 countries". Journal of Environmental Psychology, Volume 19, 255-65.

Kalafatis, S.P., Pollard, M., East, R. and Tsogas, M.H. (1999). "Green marketing and Ajzen's theory planned behaviour: A cross-market examination". Journal of Consumer Marketing, 16(5), pp. 441-460.

McCarty, J. A. and Shrum, L. J.,(2001),"The influence of individualism , collectivism, and locus of control on environmental beliefs and behaviour. Journal of Public Policy and Marketing, 20(1), pp. 93-104.

Kim, Y., and Choi, S.M. (2005),"Antecedents of green purchase behaviour: An examination of collectivism, environmental concern and PCE", advances in consumer research, vol, 32, pp.592599.

P. Rao, Journal of Asia Business Studies, vol.1, pp. 55-66, 2007.

Q. Zhu and J. Sarkis, Journal of Operations Mnagement, vol 22,pp.265-289,2004.

S. K. Srivastava, International Journal of Management Reviews. vol. 9, pp. 53-80, 2007.

Too .L., Bajracharya .B.(2013)"Sustainable campus: engaging the community in sustainability". International Journal of Sustainability in Higher Education, Vol. 16 Iss1 pp. 57-71.

Velazquez Contreras, L. (2002),"Sustainable universities around the world: a model for fostering sustainable university program's effectiveness", Doctoral dissertation, University of Massachusetts Lowell, Lowell, MA.

Allenby, B.R. (1998), "Context is everything", Journal of Industrial Ecology, Vol. 2, pp 6-8.

DEFRA (2005), The UK Government Sustainable Development Strategy, TSO.

Jackson, T. (2005),"Motivation Sustainable Consumption: A Review of Evidence on Consumer Behaviour and Behavioural Change", Canadian Centre for Pollution Prevetion, Ontario, available at: www.c2p2online.com/documents/MotivatingSC.pdf (accessed 29 August 2012).

Lundholm, C. (2005),"Learning about environmental issues", International Journal of Sustainability in Higher Education, Vol. 6 Iss 3 pp. 242-253.

Gambro, J.S. and Switzky, H.N. (1996), "A national survey of high school student's environmental knowledge ", Journal of Environmental Education, Vol.27 No. 3, pp. 28-33.

Gomez-Granell, C. and Cervera-March, S. (1993), "Development of conceptual knowledge and attitudes aobut energy and the environment", International Journal of Science Education, Vol. 15 No. 5, Special Issue: Environmental education and science education, pp. 553-65. 
Ivy, T.G.-C., Lee, C.K.-E. and Chuan, G.K. (1998), " A survey of environmental knowledge, attitudes and behaviour of students in Singapore", International Research in Geographical and Environmental Education, Vol. 7 No. 3, pp. 181-202.

Bord, R.J., O'Connor, R.E. and Fisher, A. (2000), "In what sense does the public need to understand global climate change?", Public Understanding of Science, Vol. 9 No. 3, pp. 205-218.

Chan, R.Y.K., and Lau, L. B.Y. (2000). Antecedents of Green Purchases: A survey in China. Journal of Consumer Marketing, 17(4), 338-357

Mostafa, M. M. (2007). Gender Differences in Egyptian Consumers' Green Purchase Behaviour: The Effects of Environmental Knowledge, Concern and Attitude. International Journal of Consumer Studies, 31, 220-229.

Xi, X., Lihong, F. and Xueming, D. (1998), "Public environmental awareness in China: an analysis of the results of public surveys", Center for the Integrated Study of the Human Dimensions of Global Change, Carnegie Mellon University.

Zhenmin, F. and Xiaohua, W. (2002), "Survey and education on residents' environmental awareness in Jiangsu province of China", International Journal of Environment and Pollution, Vol. 17 No. 4, pp. 312-322.

Abdul-Wahab, S.A. (2008), "A preliminary investigation into the environmental awareness of the Omani public and their willingness to protect the environment", American Journal of Environmental Sciences, Vol. 4 No. 1, pp. 33-49.

Shobeiri, S.M., Omidvar, B. and Prahallad, N.N. (2007), "A comparative study of environmental awareness among secondary school students in Iran and India", Int. J. Environ. Res, Vol. 1No. 1, pp. 28-34.

Ziadat, A.H. (2010), "Major factors contributing to environmental awareness among people in a third world country/Jordan", Environment, Development and Sustainability, Vol. 12 No. 1,pp. 135145 .

Brody, M. (1996), "An assessment of 4th-, 8th-, and 11th-grade students? knowledge related to marine science and natural resource issues", Journal of Environmental Education, Vol. 27No. 3, pp. 21-27.

Levy, B. L.M. and Marans, R. M.(2012),"Towards a campus culture of environmental sustainability", International Journal of Sustainability in Higher Education, Vol. 13 Iss 4, pp. 365-377

Kline, P. (1999). The handbook of psychological testing (2nd ed.). London: Routledge.

Strizhakova Y. and Coulter R.A. (2013)," The "green" side of materialism in emerging BRIC and developed markets: The moderating role of global cultural indentity". Intern.J. of Research in Marketing. School of Business, University of Connecticut, 2100 Hillside Road, Storrs, CT 06269-1041, United State.

Ajzen I. The Theory of Planned Behaviour. Organisational Behav Hum Decision Process 1991;50:179-211.Ajzen I, Driver BL. Application of the theory of planned behaviour to leisure choice. J Leis Res 1992;24(3):207-24.

Ajzen I., and Fishbein M. (1975),"Attitude-Behaviour Relations: A theoretical Analysis and Review of Empirical Research. Psychological Bullettin,84, 888-918. http://dx.doi.org/10.1037/00332909.84 .888

Hazen B.T. and Cegielski C. (2011),"Diffusion of green supply chain management", Examining perceived quality of green reverse logistics. The International Journal of Logistics Management, vol. 22 no.3,pp. 373-389

Azizan M.A. Wahid N.A. (2012)," a Proposed model on environment stewardship". Social and behavioural sciences 65.pp. 587-592.

Blok V., Wesselink R., Studynka O., and Kemp R. (2014) " Encouraging sustainability in the workplace: a survey on the pro-environmental behaviour of university employees". Journal of cleaner production.

Marans R.W. (2014)"Quality of urban life \& environmental sustainability studies: Future linkage opportunities". Habitat International. University of Michigan, Ann Arbor, MI, USA. 
Chin T.A., Tat H.H., and Sulaiman Z. (2015),"Green supply chain management, environmental collaboration and sustainability performance". Procedia CIRP, 26(0), 695-699.doi: http://dx.doi. org /10.1016/j.procir.2014.07.035

Blamey, Russel (1998), "The activation of environmental norms: extending Schwartz's Model", Environment and Behaviour, vol. 30.

\section{AUTHOR's BIOGRAPHY}

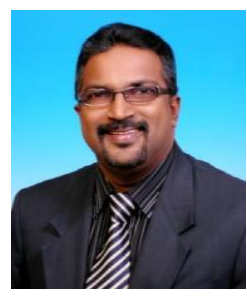

Dr. Shankar Chelliah, is currently affiliates with Universiti Sains Malaysia (USM), based in Penang, Malaysia. Prior becoming academician, he has fifteen years of corporate experiences by holding various positions in blue chip companies such as Motorola and Intel. Currently positioned in the section of International Business and teaching subjects such as international new venture, international trade law, and international business management. Dr. Shankar Chelliah has published more than 100 publications in text books, chapter in books, high impact journals (SCOPUS/ISI), and both international and local conference proceedings. Has successfully received more than RM250,000 in total grant from the government in pursuing research in the above mentioned areas. Graduated more than 10 Phd and Master students. He also actively writes in the media mass on the areas relates to his research topics to outreach the community. 